\title{
Clinical Spectrum of Patients with Renal Cell Carcinoma
}

\author{
Mehrnaz Asadi Gharabaghi \\ Tehran University of Medical Sciences \\ Iran
}

\section{Introduction}

The classic triad of flank pain, palpable mass and hematuria exists in less than 20 percent of patients with renal cell carcinoma, and the tumor may become large in its origin before any local sign or symptom arises. Therefore, it is common to detect the tumor only after the metastasis develops.

Renal cell carcinoma (RCC) may present with diverse range of clinical manifestations. Many cases of renal cell carcinoma are unsuspected initially. The same is true for tumor recurrence even several years after primary tumor resection. For instance, it is not uncommon for a thyroid nodule to be the presenting feature of metastatic RCC. Renal cell carcinoma may masquerade any other illness so it is named tumor of internal medicine. Here the clinical presentations of the tumor within different body organs are discussed. In the followings, the clinical spectrum is arranged by each system in the body. The symptoms and signs of tumor in the urinary system are discussed separately. The systemic manifestations of cancer-related treatment are not discussed here.

\section{Skin manifestations}

Dermatological manifestations of renal cell carcinoma are not common. However, there are reports of coetaneous metastases as the primary clue to the tumor diagnosis (Mueller et al., 2004; Srinivasan, 2010). Skin nodules are more common. Scalp is the most prevalent site followed by chest and abdomen (Arrabal-Polo et al, 2009; Dorairajan et al., 1999).

Small vessel vasculitis limited to skin has been noted in renal cell carcinoma. It causes papules, nodules and even skin ulceration. Maynard et al reported a case of an adult male with renal cell carcinoma that initially presented with leukocytoclastic vasculitis involving skin, joints and gastrointestinal tracts (Maynard, 2010).

Palmar fibromatosis,acanthosis nigricans,hypertrichosis lanuginose,paraneoplastic erythroderma, bullous pemphigoid, and acquired ichthyosis are rare coetaneous manifestations of internal malignancies that are rarely reported in cases of renal cell carcinoma (Klein et al., 2009; Tebbe et al.,1991).

Hence, it cannot be over emphasized that an occult cancer such as renal cell carcinoma needs to be considered in evaluation of an elderly patient presenting with systemic vasculitis or certain dermatologic disorders. 


\section{Musculoskeletal manifestations}

Renal cell carcinoma avidly involves the skeleton .After lung; the skeleton is the second most common site for metastases (Fottner et al., 2010). It ranks as the sixth solid tumor responsible for bone metastases that cause severe bone pain or debilitating skeletal complications such as pathologic fractures and spinal cord compression. Pelvis, ribs and vertebrae are the most prevalent sites for bone metastases. Patients with bone involvement portend a grave prognosis and most of them die within a year. Various therapeutic modalities such as chemo radiotherapy, surgery and bisphosphonates have been introduced with variable success (Lipton et al., 2004).

A 54 year-old man presented with multiple pathologic fractures of thoracic vertebrae to my department. He was finally diagnosed to suffer from advanced renal cell carcinoma. He was a truck driver and noticed the severe back pain while fixing his truck. The fractures occurred when he was tightening the screws forcefully. Therefore, it seems prudent to look for a kidney cancer while confronting bone metastasis with unknown origin.

Cancer and autoimmunity is a well-known inter-disciplinary entity .Tumor products behave as haptens triggering an overwhelming autoimmune response within the body. The autoimmune disorder may herald the presence of an occult cancer.

Inflammatory myopathies, myositis and inclusion body myositis are reported as paraneoplastic syndromes associated with renal cell carcinoma. Klausner et al reported a case of 45- year -old man presented with polymyosistis that finally diagnosed to have renal cell carcinoma (Klausner et al, 2002). Similarly, Respicio et al reported a case of concurrent renal cell carcinoma, interstitial lung disease and polymyositis in a 58 year-old man (Respicio et al., 2007).It is not exactly known whether it is possible to predict the type of solid tumor at the time of inflammatory mysoitis by means of tumor biologic markers. Amoura et al reported that markers as CA-125 and CA19-9 may predict developing the offending tumor in advance and need to be included in evaluation of patients with inflammatory myopathic syndromes(Amoura et al.,2005).

A syndrome resembling to polymyalgia rheumatica (PMR) has been described as a paraneoplastic manifestation of solid tumors. The syndrome is not steroid responsive. Yet, it is not clear whether it will be improved after nephrectomy (Sidhom et al., 1993). Hence, it is reasonable to look for an occult solid tumor such as renal cell carcinoma in a patient with PMR refractory to steroids. Niccoli et al reported three patients presenting with PMR mimicking syndrome heralding renal cell carcinoma. They suggested that besides inefficacy of steroids, absence of morning stiffness and characteristic sonographic findings of shoulder are features of PMR mimicking syndrome associated with RCC (Niccoli et al., 2002).

RS3PE (remitting symmetric sero negative synovitis with pitting edema) is a syndrome with symptoms similar to PMR; it occurs in patients older than 50 and may be associated with solid tumors or hematologic malignancies. It is mandatory to rule out an occult malignancy in the setting of RS3PE syndrome. Lung, breast, prostate and rarely kidney cancers have been reported as the underlying solid tumors in patients with this syndrome (Juncadella et al., 2003; Marto et al., 2010; Russel, 2005).

Other rare rheumatic manifestations of renal cell carcinoma include metastatic monoarthritis and multi centric reticulo histiocytosis (MR). The latter is a syndrome presenting with 
coetaneous nodules and severe destructive arthritis .It may be associated with an internal malignancy. Tan et al reported two cases of MR associated with urologic malignancies (Placed et al, 2010; Tan et al.2011).

\section{Nervous system manifestations}

Paraneoplastic neuropathy is a well-known autoimmune neuropathy associated with anti neuronal nuclear antibody. Roy et al (Roy et al., 2002) reported chronic sensory motor polyneuropathy in a 65-year-old man several months before the diagnosis of RCC. Allen et al also reported a case of acute demyelinating neuropathy in a case of papillary renal cell carcinoma that resolved following nephrectomy (Allen et al., 2011). Torvik et al reported three cases with necrotizing vasculitic involvement of peripheral nerves that were diagnosed to have renal cell carcinoma through postmortem follow up (Torvik \& Berntzen, 1968).

Numb chin syndrome is numbness of lower lip, chine and gingiva of anterior lower teeth. It may be associated with a visceral malignancy such as lung, breast cancer or leukemia; however, it has been reported in renal cell carcinoma. Inferior alveolar/mental nerve is involved due to metastasis to mandible or nerve sheath infiltration by tumor (Divya et al., 2010; Lata \& Kumar, 2010).

Opsoclonus is an ocular dyskinesia characterized by involuntary, repetitive, rapid conjugate saccades. It is most commonly seen in children. In an adult, it may herald an internal malignancy. Koukoulis A et al reported a case of paraneoplastic opsoclonus in a 64 year- old man. The patient was diagnosed to have papillary renal cell carcinoma 6 months after the diagnosis of opsoclonus (Koukoulis et al., 1998).

Antinueronal nuclear antibody type 1 (classically known as anti $-\mathrm{Hu}$ ) is detected in cancer associated autoimmune neurologic disorders (lucchinetti et al., 1998) .Patients develop various forms of neurologic disease including Lambert-Eaton myasthenic syndrome, encephalitis, cerebellar ataxia and so forth. For instance, Ammar et al reported a case of 64year- old woman who presented with acute cerebellar ataxia as the initial manifestation of renal cell carcinoma (Ammar et al., 2008). There is also a report of bilateral diaphragmatic paralysis as a paraneoplastic neurologic disease secondary to RCC that ameliorated after nephrectomy (Rijnders \& Decramer, 2000).Therefore, it is appropriate to investigate for an occult cancer when confronting an idiopathic bilateral diaphragmatic paralysis.

Brain and spinal metastases are common in advanced stages of RCC. However, solitary brain metastasis and relevant clinical findings such as headache and focal neurologic deficit may be the presenting signs of the cancer (Candiano et al., 2010). Spinal metastases are usually extra dural but intradural involvement with resulting neurologic deficits, especially cauda equina syndrome were reported (Lin et al., 2011). Back pain and sciatica due to metastatic nerve root infiltration of lumbo sacral nerves have been reported in RCC patients (Shakeel et al., 2009). Intramedullary spinal metastasis that are the rarest type of spinal involvement have also been reported as the presenting sign in RCC (Asadi et al., 2009; Donovan\& Freeman, 2006; Gómez de la Riva et al., 2005; Schijns et al., 2000). Although uncommon, an occult cancer such as renal cell carcinoma needs to be considered in differential diagnosis of the above-mentioned syndromes. 


\section{Vascular system manifestations}

Renal vein and caval thromboses are among the well- known thrombotic events associated with renal cell carcinoma. Left-sided varicocele that does not decompress after taking the recumbent position is a well -known complication of the locally advanced RCC. It is due to tumor thrombus extending along the renal vein that blocks drainage of left spermatic vein into inferior vena cava (IVC).It is not just left spermatic vein that may become clogged .Right spermatic vein is at risk too. Shinsaka et al reported a case of right varicocele as a result of RCC thrombus in right spermatic vein without simultaneous caval thrombosis (Al-Taan et al., 2007;Shinsaka et al., 2006).Furthermore, prothrombotic state as a paraneoplastic feature of RCC may cause thrombosis in unusual sites such as subclavian veins(Hameed et al.,2011). Hence, it is worthwhile to consider RCC in evaluating patients with idiopathic venous thrombosis, especially in an unusual site.

\section{Hematologic manifestations}

Cytopenia, especially anemia is a common feature of the tumor. Polycythemia may also be seen, although less frequently (Mohammed Ilyas et al., 2008). Although, micro angiopathic hemolytic anemia, hemolytic uremic syndrome and disseminated intravascular coagulopathy may occur because of cancer chemotherapy in RCC, the tumor rarely presents with such a hematologic manifestation as thrombocytopenia .Yet, there are reports of metastatic RCC presenting with thrombocytopenia due to bone marrow carcinomatosis (Florcken et al., 2009).

Disturbation in fibrinolysis system is a well -known feature of hematologic and nonhematologic tumors such as prostate cancer. Plasminogen is converted to plasmin; tissue plasminogen activator ( $\mathrm{PA}$ ) or urokinase- type plasminogen activator (uPA) promotes the conversion. Some tumors express high level of tPA activity. This feature not only brings some sort of bleeding diathesis but also seems to be vital for tumor survival. In fact, the variable expression of fibrinolysis system components in a given cancer may affect the prognosis. For instance, patients with greater expression of u-PA on breast cancer cells have shorter survival and increased chance of relapse (Bell, 1996).In renal cell carcinoma, it has been demonstrated that expression of plasminogen inhibitor- 1 is an independent poor prognostic factor as it promotes tumor angiogenesis and metastasis (Choi et al.,2011;Zubcaet al.,2010). Therefore, changes in hematologic parameters are not only paraneoplstic features of RCC but also of prognostic value.

\section{Pulmonary manifestations}

Lung metastases are common in natural history of RCC. Single or multiple variable -sized pulmonary nodules are usually detected in patients with advanced RCC. Regarding large reserve volume of lung, tumor burden may become so huge before any respiratory symptom such as dyspnea or cough develops. Besides this common mode of presentation, lymphangitic carcinomatosis may develop in setting of metastatic RCC. It is an interstitial lung disorder caused by lymphangitic spread of tumors such as breast, lung and rarely kidney cancer. It usually manifests with obstinate cough and progressive dyspnea. Wallach et al reported a case of 68 year -old man who presented with respiratory symptoms 20 months after nephrectomy for stage III RCC. He had lymphangitic carcinomatosis. 
According to their review of literature, there are less than 10 reports of such patients (Wallach et al., 2011).

RCC metastases are not confined to lung parenchyma. There are reports of endobronchial metastases from RCC .Therefore hemoptysis or a pulmonary atelectasis may result from endobronchial spread of RCC.As the tumor is a hyper vascular one, it is mandatory to take precaution while planning local therapeutic modalities for symptomatic metastases (Mathai et al., 2007; Suyama et al., 2011).

Malignant pleural effusion secondary to RCC is rare and usually seen with papillary and clear cell histological types. There are reports of special cases of malignant effusion secondary to RCC.As an example; Chetcuti K et al reported a case of massive spontaneous hemothorax in a 78 year- old man with a history of RCC. The culprit was a chest wall metastasis of RCC (Chetcuti et al., 2010; Teresa et al., 2011).

Mediastinal lymph adenopathy and masses are seen in advanced stages of renal cell carcinoma or as presenting features of primary tumor or tumor recurrence. They are closely correlated with poor prognosis (Mattana et al., 1996; Winter et al., 2010). Niikura $S$ et al reported a case of 62 year- old man presented with mediastinal lymph node enlargements 19 years after nephrectomy for RCC (Niikura et al., 1999).

Pulmonary infarction due to tumor emboli within pulmonary circulation is an unual manifestation of renal cell carcinoma. The tumor emboli originates from thrombus extending along vena cava, right sided heart or proximal part of pulmonary artery (Shiono et al.,2001; Wieder et al.,2003). The disease presents with acute or sub acute cor pulmonale and cytological study of pulmonary artery sample helps diagnosis.

Despite the grave prognosis associated with pulmonary involvement in patients with RCC, there is a report by Okubo $\mathrm{Y}$ et al who described a patient with an obstinate cough as the sole manifestation of non- metastatic RCC .Cough disappeared after nephrectomy and recurred with tumor relapse (Okubo et al., 2007).

\section{Cardiac manifestations}

Heart may be involved in different manners by a non-cardiac tumor. For example, certain chemotherapeutic drugs and radiotherapy have deleterious effects on heart. Opportunistic infection of cardiac chambers has been demonstrated because of immune suppression in cancer patients. The tumor may involve the pericardium and less frequently, myoendocardium.So malignant pericardial effusion is a common finding in advanced cancer patients (Kim et al., 2010). Although uncommon, there are reports of malignant pericardial effusion secondary to RCC (Zustovich et al., 2008).

In RCC, vena cava thrombosis can extend beyond the hepatic veins into the right atrium (Kalkat et al., 2008) .However; there are reports of cardiac metastasis mimicking primary cardiac tumors without concurrent cava involvement (Aburto et al., 2009; Talukder et al., 2010). For instance, Lee HJ et al demonstrated a case of 77- year- old man with 2- month history of RCC in whom cardiac metastasis caused left ventricular outflow tract obstruction (Lee et al., 2010). Miyamoto MI et al reported a case of metastatic renal carcinoma with a left atrial mass mimicking myxoma. They demonstrated that the mass was RCC metastasis 
derived from pulmonary vein tumor extension. The pulmonary vein itself had been involved from adjacent mediastinal lymph nodes (Miyamoto\& Picard, 2002). Cardiac metastasis in a patient with known history of primary cancer is not challenging to diagnosis. Yet it is not uncommon for a RCC to present initially with a cardiac mass (Crouch \& Tak,2002).Therefore, it needs to be vigilant to the presence of an occult cancer when evaluating a cardiac mass even if it resembles a primary cardiac tumor and there is no extra cardio respratory symptom.

Not only myopericardium is involved in RCC but also the endocardium may become diseased in RCC. Non-bacterial endocarditis is a well -known disease entity in various diseases such as HIV infection, connective tissue disorders and cancers. The exact mechanism is not yet defined but thrombophilic state associated with malignancy may be responsible. The most primary cancer site is pancreas (Johnson et al., 2010). In literature review, there is few report of RCC associated with non-bacterial thrombotic endocarditis.

\section{Gastrointestinal manifestations}

Gastrointestinal (GI) tract is involved by RCC in different ways. Stauffer's syndrome constitutes reversible abnormalities in liver function tests including enzymes and pro thrombin time. It may present as hepatocellular or cholestatic liver disease. It is not due to liver metastasis and actually caused by humoral effects of inflammatory cytokines produced by the tumor. Therefore, the abnormalities disappear after tumor resection by nephrectomy (Kranidiotis et al., 2009). However, there are reports of renal cell carcinoma metastases to various organs of gastrointestinal tracts.

Oral cavity metastases from RCC have been demonstrated. In fact, intraoral soft tissue metastases are not common. They usually originate from lung and breast cancers. Metastatic oral cavity lesions rarely present as the initial feature of an occult cancer. For instance, Maestre-Rodríguez $\mathrm{O}$ reported a case of 55- year-old man who underwent resection of a gingival tumor that finally diagnosed to be metastatic RCC (Will et al., 2008; MaestreRodríguez et al., 2009). Esophageal metastasis producing local symptoms such as dysphagia is not surprising in a case of an advanced RCC (de los Monteros-Sanchez et al., 2004). Hematogenous spread of RCC to stomach is seen, albeit with concomitant metastases in other organs, especially lungs (Pollheimer et al., 2008).Although uncommon, gastric metastasis and upper gastrointestinal bleeding may be the initial feature of RCC. Tiwari P et al reported a 58- year-old woman with a 2-week history of melena. The source of bleeding was a $3 \mathrm{~cm} \times 5 \mathrm{~cm}$ vascular polypoid antral mass. She was finally diagnosed to have metastatic RCC (Tiwari et al., 2010).

Intraluminal metastases from RCC may be the source of intestinal bleeding or less commonly intussusceptions. They may behave as the leading point for an intestinal obstruction and intussusceptions. Periampullary region, duodenum and jejunum rank the most common sites .Yet, other sites as large bowel may be involved too (Eo et al., 2008; Loualidi et al., 2004; Nozawa et al., 2003; Papachristodoulou et al., 2004; Roviello et al., 2006; Sadler et al., 2007 Takeda et al., 2011). The above cases highlight the importance of considering RCC metastasis as a source of intestinal bleeding and/or obstruction, especially in patients with a known cancer history. 
Liver is the organ that is frequently involved in advanced RCC (Staehler et al., 2010). Yet it is not the only solid organ within GI tract involved by RCC. Pancreatic metastasis may occur due to a close proximity to the left kidney. However, the pancreas may be involved as a nest for metastatic deposits even years after nephrectomy. Yokonishi $\mathrm{T}$ et al reported pancreatic metastasis in a 74 year -old man who had history of nephrectomy due to RCC 25 years before (Yokonishi et al., 2010). The physicians must be alert to pancreatic metastasis from renal cell carcinoma and differentiate it from primary tumors of the gland because the prognosis differs in each case. Ghavamian $\mathrm{R}$ et al reviewed 23 patients with metastatic RCC to the pancreas.They found that imaging features of metastatic RCC resembled the primary RCC and differed from pancreatic tumours such as adenocarcinoma. RCC is a hyper vascular tumour, hence the metastasis enhances in early phase of contrasted abdominal computed tomography. They also noticed that the mean interval for pancreatic metastases to develop after nephrectomy was 9.8 years (Ghavamian et al., 2000).

Budd-Chiari syndrome defined by presence of abdominal pain, hepatomegaly and ascites has also been reported as a manifestation of renal cell carcinoma. The syndrome caused by tumor thrombus extending along vena cava. As a result, hepatic venous drainage system will be blocked .It may become fulminate if not treated on time (Moragnoni et al., 2010; Shih et al., 2009).

Bowel ischemia may be seen in RCC not only as a complication of immunotherapy but also as a consequence of embolic infarcts from tumor thrombus in left heart (Low et al.,1989;Sparano etal.,1991).

Sinistral portal hypertension refers to gastric variceal hemorrhage secondary to splenic vein thrombosis. It is most common in the setting of pancreatic pathologies such as pancreatitis, pseudocysts and cancer. There is no concurrent liver dysfunction (Singhal et al., 2006). Joya Seijo MD et al reported a case of sinistral portal hypertension and gastric bleeding as the initial manifestation of left sided RCC infiltrating the pancreas (Joya Seijo et al., 2004). RCC may rarely present with variceal bleeding. A 51- year- old man presented to our hospital with an episode of upper gastrointestinal bleeding twelve years after nephrectomy for a clear cell RCC. He was diagnosed to have downhill esophageal varices. They were formed by compressing effects of enlarged mediastinal lymph nodes upon the azygous vein .Pathologic review of the lymph nodes revealed recurrence of clear cell carcinoma.

\section{Endocrinologic system}

Like any other organ, endocrine system is not safe from RCC. Metastatic RCC may invade pituitary gland and mimics a nonfunctional pituitary adenoma (Kramer et al., 2010). Panhypopituitarism, suprasellar extension, headache, hemianopia, galactorrhea and diabetes insipidus are reported because of RCC metastasis to pituitary gland (Gopan et al., 2007). Although uncommon, thyroid metastasis in RCC has been demonstrated that can be of diagnostic challenge to be differentiated from primary thyroid tumors (Cimino-Mathews et al,2011).Adrenal, testicular and ovarian metastases have been reported in the course of disease even years after primary nephrectomy (Guney et al.,2010;Wu et al.,2010). Toquero L et al reported a case of 54- year old woman with a pelvic mass as an initial presentation of RCC. The mass was actually ovarian metastasis from RCC (Toquero et al., 2009).Ovarian metastases usually originate from stomach, colon, breast cancers and lymphoma. However, 
RCC needs to be considered in differential diagnosis. The patients with this sort of metastasis in either testis or ovary usually seek medical care because of localized symptoms rather than a symptom relevant to hypogonadism.It is may be due to age of patients who are usually in 50s-70s.

\section{Paraneoplastic syndromes}

There are constellation of signs, symptoms and laboratory data abnormalities not related to tumor local effect or its metastases. Some of them such as Stauffer's syndrome have been mentioned above. Most of them are cytokine mediated such as neoplastic fever (Alsirafy et al., 2011) .The remaining may be due to tumor products. Humoral hypercalcemia of malignancy is a paraneoplastic feature of various tumors. In RCC, it is multi factorial. Widespread bone metastases, parathormone-related peptide and increased production of 1 , 25 hydroxyvitamin D are responsible. Therefore, hypercalcaemia in patients with RCC may respond to administration of steroids (Shivnani et al., 2009).

Glucose metabolism abnormalities have been demonstrated in association with RCC. The tumor can produce insulin like growth factor II resulting in hypoglycemia (Berman \& Harland, 2001).On the other hand, hyper glycemia is reported as a paraneoplastic endocrinopathy in patients with RCC(Jobe et al.,1993).For instance, Yumura Y et al reported 2 patients whose diabetes was controlled after nephrectomy for RCC (Yumura et al.,2007).

Although hypertension is a complication of targeted therapy in RCC patients, it may develop as a paraneoplastic feature of kidney cancer not related to treatment (kirkali,2011).Some of the patients show increased blood level of renin and plasma renin activity as a possible cause of their increased blood pressure(Steffens et al.,1992).

Gynecomastia attributable to human chorionic gonadotropin overproduction has been reported as another paraneoplastic endocrinopathy in RCC (Mohammed Ilyas et al., 2008).It has also been demonstrated that expression of beta subunit of human chorionic gonadotropin is associated with adverse prognosis in RCC (Hotakainen et al., 2002, 2006).

Cancerous erythrocytosis is another rare para neoplastic disorder associated with RCC caused by over expression of erythropoietin and hypoxemia induced factor. However, only a small percentage of patients with over expression of erythropoietin develop paraneoplastic erythrocytosis (Wiesener et al., 2007).Although uncommon, paraneoplastic erythrocytosis of RCC may have grave sequels; Kruyt ND et al reported a case of 65- year old man who presented with neurologic deficits due to multiple cerebral infarctions as the initial presentation of RCC. His erythrocytosis and cognitive dysfunction relieved after nephrectomy for newly diagnosed RCC (Kruyt \& Wessels, 2006).

Although above-mentioned paraneoplastic syndromes are not common in RCC, they are of value for both diagnosis and estimating the prognosis of the primary tumor.

\section{Miscellaneous abnormalities}

RCC behaves unpredictably so it is common to confront its metastasis in unusual sites. The followings are some examples. It has been reported that renal cell carcinoma may initially present as an orbital mass, a mass within paranasal sinuses, gallbladder metastasis, cerebellopontine angle or superior vena cava syndrome due to supraclavicular lymph nodes 
involvement (Cobo-Dolset al., 2006; Fang et al., 2010; Panarese et al., 2002; sakura et al., 2007; Mudiayanselage et al., 2008).

\section{Conclusion}

The classic triad of flank pain, hematuria and palpable abdominal mass occurs in a small fraction of patients with renal cell carcinoma, so it is wise to be aware of various clinical presentations of the disease. The above-mentioned clinical features are summarized in Table- 1 .

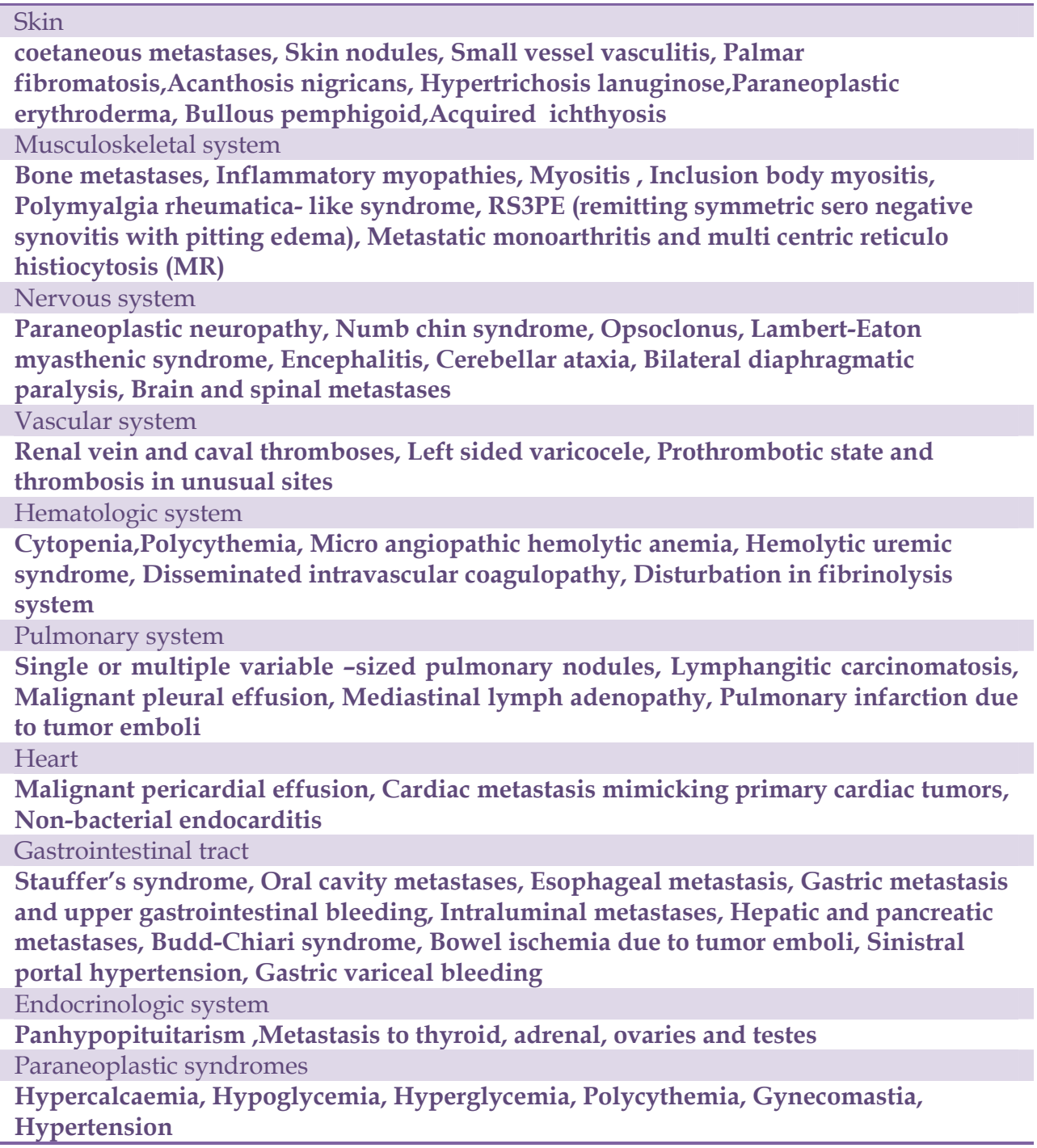

Table 1. Clinical spectrum of patients with renal cell carcinoma 


\section{References}

Aburto, J., Bruckner, BA. Blackmon, SH., Beyer, EA. \&Reardon, MJ. (2009). Renal cell carcinoma, metastatic to the left ventricle. Tex Heart Inst J., 36(1):48-9, 19436786.

Allen, JA., Yang, XJ. \& Sufit, RL. (2011).Reversible demyelinating neuropathy associated with renal cell carcinoma. Neuromuscular Disord, 21(3):227-31, 21195618.

Alsirafy, SA., El Mesidy, SM., Abou-Elela, EN. \& Elfaramawy, YI. (2011). Naproxen test for neoplastic fever may reduce suffering.J Palliat Med., 14(5):665-7, 21291328.

Al-Taan, OS. Featherstone, JM., Rees, AM., Young, WT. \& Stephenson TP. (2007).Renal cell carcinoma in a horseshoe kidney presenting as an acute, left sided varicocele.Int Urol Nephrol., 39(2):369-71, 16835726.

Ammar, H., Brown, SH., Malani, A., Sheth, HK., Sollars, EG., Zhou, SX., Gupta ,C. \&Mughal ,S. (2008 May). A case of paraneoplastic cerebellar ataxia secondary to renal cell carcinoma.South Med J., 101(5):556-7, 18414160.

Amoura, Z., Duhaut ,P., Huong, DL., Wechsler, B., Costedoat-Chalumeau, N., Francès, C., Cacoub ,P., Papo ,T, Cormont ,S., Touitou, Y., Grenier, P., Valeyre, D.\& Piette, JC.(2005). Tumor antigen markers for the detection of solid cancers in inflammatory myopathies.Cancer Epidemiol Biomarkers Prev., 14(5):1279-82, 15894686.

Arrabal-Polo, MA. Arias-Santiago, SA. Aneiros-Fernandez, J., Burkhardt-Perez, P., ArrabalMartin, M., \&Naranjo-Sintes, R. (2009). Cutaneous metastases in renal cell carcinoma: a case report. report. Cases J., 25; 2:7948-51, 19918439.

Asadi, M., Rokni-Yazdi, H., Salehinia, F. \& Allameh, FS. (2009). Metastatic renal cell carcinoma initially presented with an intramedullary spinal cord lesion: a case report.Cases J., 2:7805-8, 19918485.

Bell, WR. (1996). The fibrinolytic system in neoplasia.Semin Thromb Hemost. , 22(6):459-78, 9122711.

Berman, J. \&Harland, S. (2001).Hypoglycaemia caused by secretion of insulin-like growth factor 2 in a primary renal cell carcinoma.Clin Oncol (R Coll Radiol). , 13(5):367-9, 11716231.

Candiano, G., Pepe, P., Grasso, G. \&Aragona, F. (2010).Headache: a unique clinical presentation for renal cell carcinoma (RCC).Arch Ital Urol Androl. , 82(4):184-6, 21341558.

Chetcuti, K., Barnard, J., Loggos, S., Hassan, M., Srivastava, V., Mourad, F., Makhzoum, Z. \& Bittar, MN. (2010). Massive hemothorax secondary to metastatic renal carcinoma.Ann Thorac Surg., 89(6):2014-6, 20494072.

Choi, JW., Lee, JH., Park, HS. \& Kim, YS. (2011).PAI-1 expression and its regulation by promoter 4G/5G polymorphism in clear cell renal cell carcinoma.J Clin Pathol., July1, (Epub head of print), 21725041.

Cimino-Mathews, A., Sharma, R., \&Netto, GJ. (2011). Diagnostic use of PAX8, CAIX, TTF-1, and TGB in metastatic renal cell carcinoma of the thyroid.Am J Surg Pathol. , 35(5):757-61.21451364.

Cobo-Dols, M., Alés-Díaz, I., Villar-Chamorro, E., Gil-Calle, S., Alcaide-García, J., MontesaPino, A., Gutiérrez-Calderón, V. \& Benavides-Orgaz, M. (2006).Solitary metastasis in a nasal fossa as the first manifestation of a renal carcinoma.Clin Transl Oncol. , 8(4):298-300, 16648109.

Crouch, ED. \& Tak, T. (2002).Renal cell carcinoma presenting as right atrial mass.Echocardiography, 19(2):149-51, 11926979 de los Monteros-Sanchez, AE., Medina-Franco, H., Arista-Nasr, J. \& Cortes-Gonzalez ,R. (2004). Resection of an 
esophageal metastasis from a renal cell carcinoma.Hepatogastroenterology, 51(55):163-4, 15011855.

Divya, KS., Moran, NA. \& Atkin, PA. (2010). Numb chin syndrome: a case series and discussion. Br Dent J., 208(4):157-60, 20186196.

Donovan, DJ. \&Freeman, JH. (2006). Solitary intramedullary spinal cord tumor presenting as the initial manifestation of metastatic renal cell carcinoma: case report.Spine (Phila Pa 1976). , 15; 31(14):E460-3., 16778676.

Dorairajan ,LN., Hemal ,AK., Aron, M., Rajeev, TP., Nair, M., Seth, A., Dogra, PN.\&Gupta, NP.(1999). Cutaneous metastases in renal cell carcinoma.Urol Int. , 63(3):164-7, 10738187.

EO, WK., Kim, GY. \& Choi, SI. (2008). A case of multiple intussusceptions in the small intestine caused by metastatic renal cell carcinoma.Cancer Res Treat. , 40(2):97-9, 19688056.

Fang, X., Gupta, N., Shen, SS., Tamboli, P., Charnsangavej, C., Rashid, A. \& Wang, H. (2010).Intraluminal polypoid metastasis of renal cell carcinoma in gallbladder mimicking gallbladder polyp.Arch Pathol Lab Med., 134(7):1003-9, 20586628.

Florcken ,A., Loew, A., Koch, M., Gebauer, B., Dorken, B. \& Riess, H. (2009).Severe thrombocytopenia in a patient with metastatic renal cell carcinoma.Onkologie. , 32(11):670-2, 19887872.

Fottner, A., Szalantzy, M., Wirthmann, L., Stähler, M., Baur-Melnyk, A., Jansson, V. \&Dürr, HR. (2010).Bone metastases from renal cell carcinoma: patient survival after surgical treatment.BMC Musculoskelet Disord. , 3; 11:145-50, 20598157.

Ghavamian, R., Klein, KA., Stephens, DH., Welch, TJ., LeRoy, AJ., Richardson, RL., Burch, PA. \&Zincke H. (2000). Renal cell carcinoma metastatic to the pancreas: clinical and radiological features.Mayo Clin Proc., 75(6) :581-5, 10852418.

Gómez de la Riva, A., Isla ,A., Pérez-López, C., Budke, M., Gutiérrez, M. \& Frutos, R. (2005). [Intramedullary spinal cord metastasis as the first manifestation of a renal carcinoma].Neurocirugia (Astur). , 16(4):359-64, 16143809.

Gopan, T., Toms, SA., Prayson ,RA., Suh, JH., Hamrahian, AH. \& Weil, RJ. (2007). Symptomatic pituitary metastases from renal cell carcinoma.Pituitary, 10(3):251-9, 17541748.

Guney, S., Guney, N., Ozcan, D., Sayilgan, T. \& Ozakin, E. (2010).Ovarian metastasis of a primary renal cell carcinoma: case report and review of literature.Eur J Gynaecol Oncol. , 31(3):339-41, 21077484.

Hameed, A., Pahuja, A., Thwaini, A. \&Nambirajan, T. (2011).Subclavian vein thrombosis: an unusual presentation of renal cell carcinoma. Can Urol Assoc J., 5(2):E27-8, 21470547.

Hotakainen, K., Lintula, S., Ljungberg, B., Finne, P., Paju, A., Stenman, UH. \&Stenman ,J. (2006).Expression of human chorionic gonadotropin beta-subunit type I genes predicts adverse outcome in renal cell carcinoma.J Mol Diagn. , 8(5):598-603, 17065429.

Hotakainen, K., Ljungberg, B., Paju, A., Rasmuson, T., Alfthan, H. \& Stenman, UH. (2002). The free beta-subunit of human chorionic gonadotropin as a prognostic factor in renal cell carcinoma.Br J Cancer. , 86(2):185-9, 11870503.

Jobe ,BA., Bierman, MH. \& Mezzacappa, FJ. (1993). Hyperglycemia as a paraneoplastic endocrinopathy in renal cell carcinoma: a case report and review of the literature.Nebr Med J., 78 (11):349-51, 8309485. 
Johnson, J.A., Everett, B.M., Katz, J.T. \& Loscalzo, J. (2010).Clinical Problem-Solving Painful Purple Toes. N Engl J Med., 362:67 - 73, 0807291.

Joya Seijo, MD., del Valle Loarte, P., Marco Martínez, J., Herrera Merino, N.\& Agud Aparicio, JL.(2004). carcinoma. An Med Interna., 21(6):283-4, 15283642.

Juncadella, E., Ramentol, M., Rozadilla, A., \&Ferre, J . (2003). RS3PE syndrome and renal cancer. Med Clin (Barc)., 8;121(16):638-9, 14636547.

Kalkat, MS., Abedin, A., Rooney, S., Doherty, A., Faroqui, M., Wallace, M. \& Graham, TR. (2008).Renal tumours with cavo-atrial extension: surgical management and outcome.Interact Cardiovasc Thorac Surg., 7(6):981-5, 18550606.

Kim, SH., Kwak, MH., Park, S., Kim, HJ., Lee, HS., Kim, MS., Lee, JM., Zo, JI., Ro, JS. \& Lee, JS. (2005). Clinical characteristics of malignant pericardial effusion associated with recurrence and survival. Cancer Res Treat. , 42(4):210-6, 21253323.

Kirkali, Z. (2011).Adverse events from targeted therapies in advanced renal cell carcinoma: the impact on long-term use.BJU Int., 107(11):1722-32, 21251188.

Klausner, AP., Ost, MC., Waterhouse RL ,Jr. \&Savage SJ. (2002). Occult renal cell carcinoma in a patient with polymyositis.Urology. , 59(5):773-6, 11992921.

Klein, T., Rotterdam, S., Noldus, J. \&Hinkel, A. (2009). Bullous pemphigoid is a rare paraneoplastic syndrome in patients with renal cell carcinoma. Scand J Urol Nephrol. , 43(4):334-6, 19308806.

Koukoulis ,A., Cimas, I. \&Gómara, S. (1998).Paraneoplastic opsoclonus associated with papillary renal cell carcinoma. J Neurol Neurosurg Psychiatry., 64(1):137-8, 9436748.

Kramer, CK., Ferreira, N., Silveiro, SP., Gross, JL., Dora, JM. \&Azevedo, MJ. (2010).Pituitary gland metastasis from renal cell carcinoma presented as a non-functioning macroadenoma.Arq Bras Endocrinol Metabol. , 54(5) :498-501,20694412.

Kranidiotis, GP., Voidonikola, PT., Dimopoulos, MK. \& Anastasiou-Nana, MI. (2009). Stauffer's syndrome as a prominent manifestation of renal cancer: a case report. Cases J., 2(1):49-52, 19144140.

Kruyt ND\& Wessels PH. (2006).Cerebral infarction due to polycythaemia as the initial manifestation of renal cell carcinoma.Ned Tijdschr Geneeskd. , 150(17):969-72, 17225738.

Lata, J\& Kumar, P. (2010). Numb chin syndrome: a case report and review of the literature. Indian J Dent Res. , 21(1):135-7, 20427925.

Lee, HJ., Park, JI., Lim, BH., Seo, JW., Kang, EM., Lee, BU. \& Kim, YJ. (2010). Left ventricular metastasis from renal cell carcinoma causing left ventricular outflow tract obstruction. Korean Circ J., 40(8):410-3, 20830256.

Lin, TK., Chen, SM. \& Jung, SM. (2011).Solitary intradural extramedullary metastasis of renal cell carcinoma to the conus medullaris.Kaohsiung J Med Sci., 27(1):45-8, 21329893.

Lipton, A., Colombo-Berra, A., Bukowski, RM., Rosen, L., Zheng, M. \&Urbanowitz, G. (2004).Skeletal complications in patients with bone metastases from renal cell carcinoma and therapeutic benefits of zoledronic acid.Clin Cancer Res., 15; 10(18 Pt 2):6397S-403S, 15448038.

Loualidi, A., Spooren, PF., Grubben, MJ., Blomjous, CE. \& Goey, SH. (2004).Duodenal metastasis: an uncommon cause of occult small intestinal bleeding.Neth J Med., 62(6):201-5, 15460501. 
Low, DE. Frenkel, VJ., Manley, PN., Ford, SN. \& Kerr, JW. (1989). Embolic mesenteric infarction: a unique initial manifestation of renal cell carcinoma. Surgery, 106(5):925-8, 2683176.

Lucchinetti, CF., Kimmel, DW. \&Lennon, VA. (1998). Paraneoplastic and oncologic profiles of patients seropositive for type 1 antineuronal nuclear autoantibodies. Neurology. , 50(3):652-7, 9521251.

Marangoni, G., O'Sullivan, A., Ali, A., Faraj, W. \& Heaton, N. (2010).Budd-Chiari syndrome secondary to caval recurrence of renal cell carcinoma.Hepatobiliary Pancreat Dis Int., 9(3):321-4, 20525562.

Marto, G., Klitna, Z., Biléu, MC. \& Barcelos, A. (2010). Remitting seronegative symmetric synovitis with pitting oedema syndrome, associated with prostate adenocarcinoma: a cse report.Acta Reumatol Port. , 35(3) :358-60, 20975640.

Mathai, AM., Rau, AR., Shetty, AB., Kamath, MP. \& Prasad, SC. (2007). Endobronchial metastasis from renal cell carcinoma: a case report. Indian J Pathol Microbiol. , 50(2):379-81, 17883082.

Mattana, J., Kurtz, B., Miah, A. \& Singhal, PC. (1996). Renal cell carcinoma presenting as a solitary anterior superior mediastinal mass.J Med., 27(3-4):205-10, 8289968.

Maynard, JW., Christopher-Stine, L. \& Gelber, AC. (2010). Testicular pain followed by microscopic hematuria, a renal mass, palpable purpura, polyarthritis, and hematochezia.J Clin Rheumatol., 16 (8):388-91, 21085014.

Miyamoto, MI. \& Picard, MH. (2002). Left atrial mass caused by metastatic renal cell carcinoma: an unusual site of tumor involvement mimicking myxoma.J Am Soc Echocardiogr. , 15(8):847-8, 12174358.

Mohammed Ilyas, MI., Turner, GD. \& Cranston, D. (2008). Human chorionic gonadotropinsecreting clear cell renal cell carcinoma with paraneoplastic gynaecomastia.Scand J Urol Nephrol. , 42(6):555-7, 19031270.

Mueller, TJ., Wu, H., Greenberg, RE., Hudes, G., Topham, N., Lessin, SR. \&Uzzo RG. (2004). Cutaneous metastases from genitourinary malignancies.Urology, 63 (6):1021-6, 15183939.

Niccoli, L., Salvarani, C., Baroncelli, G., Padula, A., Olivieri, I. \&Cantini F. (2002).Renal cell carcinoma mimicking polymyalgia rheumatica. Clues for a correct diagnosis.Scand J Rheumatol. , 31(2):103-6, 12109644.

Niikura, S., Hirata, A., Kunimi, K., Yokoyama, O., Koshida, K., Uchibayashi, T., Namiki, M., Nishino, A. \& Kameda, K. (1999). Renal cell carcinoma recurrence in the mediastinum lymph node 19 years after nephrectomy: a case report.Hinyokika Kiyo. , 45(6):419-21, 10442285.

Nozawa, H., Tsuchiya, M., Kobayashi, T., Morita, H., Kobayashi, I., Sakaguchi, M., Mizutani, T., Tajima, A., Kishida, Y., Yakumaru, K., Kagami, H. \& Sekikawa, T. (2003).Small intestinal metastasis from renal cell carcinoma exhibiting rare findings.Int J Clin Pract. , 57(4):329-31, 12800466.

Okubo, Y., Yonese, J., Kawakami, S., Yamamoto, S., Komai, Y., Takeshita, H., Ishikawa, Y. \& Fukui, I. (2007).Obstinate cough as a sole presenting symptom of non-metastatic renal cell carcinoma.Int J Urol., 14(9):854-5, 17760755.

Panarese, A., Turner, J. \& Fagan, PA. (2002). Renal carcinoma metastasis: an unusual cerebellopontine angle tumor.Otolaryngol Head Neck Surg., 127(3):245-7, 12297820. 
Papachristodoulou, A., Mantas, D., Kouskos, E., Hatzianastassiou, D. \& Karatzas, G. (2004).Unusual presentation of renal cell carcinoma metastasis.Acta Chir Belg., 104(2):229-30, 15154588.

Placed, IG., Alvarez-Rodriguez, R., Pombo-Otero, J., Vázquez-Bartolomé, P., HermidaRomero, T.\& Pombo-Felipe, F.(2010). Metastatic renal cell carcinoma presenting as shoulder monoarthritis: diagnosis based on synovial fluid cytology and immunocytochemistry.Acta Cytol. , 54(5) :730-3, 20968165.

Pollheimer, MJ., Hinterleitner, TA., Pollheimer, VS., Schlemmer, A. \&Langner, C. (2008). Renal cell carcinoma metastatic to the stomach: single-centre experience and literature review. BJU Int. , 102 (3):315-9, 18336607.

Respicio, G., Shwaiki, W. \& Abeles, M. (2007).A 58-year-old man with anti-Jo-1 syndrome and renal cell carcinoma: a case report and discussion.Conn Med., 71(3):151-3, 17405398.

Rijnders, B. \& Decramer, M. (2000). Reversibility of paraneoplastic bilateral diaphragmatic paralysis after nephrectomy for renal cell carcinoma. Ann Oncol. , 11(2):221-5, 10761760.

Roviello, F., Caruso, S., Moscovita Falzarano, S., Marrelli, D., Neri, A., Rampone, B., De Marco, G., Perrotta, ME. \& Mariani, F. (2006).Small bowel metastases from renal cell carcinoma: a rare cause of intestinal intussusception.J Nephrol. 19(2):234-8, 16736429.

Roy, MJ., May, EF. \& Jabbari B. (2002). Life-threatening polyneuropathy heralding renal cell carcinoma.Mil Med., 167(12):986-9, 12502172

Russell EB. (2005). Remitting seronegative symmetrical synovitis with pitting edema syndrome: followup for neoplasia.J Rheumatol. , 32(9):1760-1, 16142875.

Sadler, GJ., Anderson, MR., Mos, MS. \& Wilson, PG. (2007).Metastases from renal cell carcinoma presenting as gastrointestinal bleeding: two case reports and a review of the literature.BMC Gastroenterol. , 7:4-7, 17766757.

Sakura, M., Tsujii, T., Yamauchi, A., Tadokoro, M., Tsukamoto, T., Kawakami, S., Yonese, J. \& Fukui, I. (2007). Superior vena cava syndrome caused by supraclavicular lymph node metastasis of renal cell carcinoma.Int J Clin Oncol. , 12(5):382-4, 17729122.

Schijns, OE., Kurt, E., Wessels, P., Luijckx, GJ. \& Beuls, EA. (2000). Intramedullary spinal cord metastasis as a first manifestation of a renal cell carcinoma: report of a case and review of the literature.Clin Neurol Neurosurg. , 102(4):249-254, 11154816.

Shakeel, M., Kumaravel, M., Mackenzie, JM. \&Knight, DJ. (2009). An uncommon cause of sciatica.J Coll Physicians Surg Pak., 19(2):127-9, 19208321.

Shih, KL., Yen ,HH., Su ,WW., Soon ,MS., Hsia, CH.\& Lin ,YM.(2009). Fulminant BuddChiari syndrome caused by renal cell carcinoma with hepatic vein invasion: report of a case.Eur J Gastroenterol Hepatol. , 21(2):222-4, 19212212.

Shinsaka, H., Fujimoto, N. \& Matsumoto, T. (2006).A rare case of right varicocele testis caused by a renal cell carcinoma thrombus in the spermatic vein.Int J Urol., 13 (6):844-5, 16834679.

Shiono, Y., Kishimoto, K., Furuta, N., Igarashi, H., Hatano, T., Miki, K., Oishi, Y.\& Kiyota, H. (2001). Pulmonary infarction caused by the spontaneous migration of the vena caval tumor thrombus of right renal cell carcinoma: a case report.Hinyokika Kiyo .Acta urologica japoniva. , 47(11):781-4, 11771170.

Shivnani, SB., Shelton, JM., Richardson, JA. \& Maalouf, NM. (2009). Hypercalcemia of malignancy with simultaneous elevation in serum parathyroid hormone--related 
peptide and 1, 25-dihydroxyvitamin $\mathrm{D}$ in a patient with metastatic renal cell carcinoma.Endocr Pract. , 15(3):234-9, 19364692.

Sidhom, OA., Basalaev, M. \& Sigal LH. (1993). Renal cell carcinoma presenting as polymyalgia rheumatica. Resolution after nephrectomy. Arch Intern Med., 13; 153(17):2043-5, 8357289.

Singhal, D., Kakodkar, R., Soin, AS., Gupta, S. \& Nundy, S. (2006). Sinistral portal hypertension .a case report. JOP. , 10; 7(6):670-3, 17095850.

Sparano, JA., Dutcher, JP., Kaleya, R., Caliendo, G., Fiorito, J., Mitsudo, S., Shechner, R., Boley, SJ., Gucalp, R. \& Ciobanu, N. (1991). Colonic ischemia complicating immunotherapy with interleukin-2 and interferon-alpha. Cancer, 68(7):1538-44, 1893354.

Srinivasan, N., Pakala, A., Al-Kali, A., Rathi, S. \& Ahmad, W. (2010). Papillary renal cell carcinoma with cutaneous metastases. Am J Med Sci., 339(5):458-61, 20234300.

Staehler, MD., Kruse, J., Haseke, N., Stadler, T., Roosen, A., Karl, A., Stief, CG., Jauch, KW. \&Bruns, CJ. (2010). Liver resection for metastatic disease prolongs survival in renal cell carcinoma: 12-year results from a retrospective comparative analysis. World J Urol., 28(4):543-7, 20440505.

Steffens, J., Bock, R., Braedel, HU., Isenberg, E., Bührle, CP. \& Ziegler, M. (1992). Reninproducing renal cell carcinomas--clinical and experimental investigations on a special form of renal hypertension.Urol Res., 20(2):111-5, 1553788.

Suyama, H., Igishi, T., Makino, H., Kaminou, T., Hashimoto, M., Sumikawa, T., Tatsukawa, T. \&Shimizu, E. (2011). Bronchial artery embolization before interventional bronchoscopy to avoid uncontrollable bleeding: a case report of endobronchial metastasis of renal cell carcinoma. Intern Med., 50(2):135-9, 21245638.

Takeda, T., Shibuya, T., Osada, T., Izumi, H., Mitomi, H., Nomura, O., Suzuki, S., Mori, H., Matsumoto, K., Kon, K., Abe, W., Beppu, K., Sakamoto, N., Nagahara, A., Otaka, M., Ogihara, T., Yao, T. \&Watanabe S. (2011). Metastatic renal cell carcinoma diagnosed by capsule endoscopy and double balloon endoscopy. Med Sci Monit. , 17(2):CS15-7, 21278196.

Talukder, MQ., Deo, SV., Maleszewski ,JJ. \& Park SJ. (2010). Late isolated metastasis of renal cell carcinoma in the left ventricular myocardium.Interact Cardiovasc Thorac Surg., 11(6):814-6, 20847070.

Tan, BH., Barry, CI., Wick, MR., White, KP., Brown, JG., Lee, A., Litchfield, AH., Lener, EV.\&Shitabata, PK.(2011). Multicentric reticulohistiocytosis and urologic carcinomas: a possible paraneoplastic association. J Cutan Pathol. , 38(1):43-8, 20726933.

Tebbe, B., Schlippert, U., Garbe, C. \& Orfanos, CE. (1991). Erythroderma "en nappes claires" as a marker of metastatic kidney cancer. Lasting, successful treatment with rIFNalpha-2a.Hautarzt. , 42(5):324-7, 1831444.

Teresa, P., Maria Grazia, Z., Doriana, M., Irene, P. \& Michele, S. (2011).Malignant effusion of chromophobe renal-cell carcinoma: Cytological and immunohistochemical findings.Diagn Cytopathol. , Jan 6. [Epub ahead of print], 21213172.

Tiwari, P., Tiwari, A., Vijay, M., Kumar, S. \& Kundu, AK. (2010). Upper gastro-intestinal bleeding - Rare presentation of renal cell carcinoma.Urol Ann., 2(3):127-9, 20981203.

Toquero, L., Aboumarzouk, OM. \& Abbasi, Z. (2009). Renal cell carcinoma metastasis to the ovary: a case report. Cases J., 2:7472-5, 19829972. 
Torvik, A. \& Berntzen, AE. (1968). Necrotizing vasculitis without visceral involvement. Postmortem examination of three cases with affection of skeletal muscles and peripheral nerves.Acta Med Scand., 184(1-2):69-77, 4387508.

Wallach, JB., McGarry, T. \& Torres, J.(2011).Lymphangitic metastasis of recurrent renal cell carcinoma to the contralateral lung causing lymphangitic carcinomatosis and respiratory symptoms.Curr Oncol. , 18(1):e35-7, 21311270.

Wieder, JA., Laks, H., Freitas, D., Marmureanu, A. \& Belldegrun, A. (2003). Renal cell carcinoma with tumor thrombus extension into the proximal pulmonary artery.J Urol. , 169(6):2296-7, 12771776.

Wiesener, MS., Münchenhagen, P., Gläser, M., Sobottka, BA., Knaup, KX., Jozefowski, K., Jürgensen, JS., Roigas, J., Warnecke, C., Gröne, HJ., Maxwell, PH., Willam, C.\& Eckardt, KU. (2007). Erythropoietin gene expression in renal carcinoma is considerably more frequent than paraneoplastic polycythemia.Int J Cancer. , 121(11):2434-42, 17640059.

Will, TA., Agarwal, N. \& Petruzzelli,GJ. (2008). Oral cavity metastasis of renal cell carcinoma: a case report.J Med Case Reports. , 2:313-6, 18823541.

Winter, H., Meimarakis, G., Angele, MK., Hummel, M., Staehler, M., Hoffmann, RT., Hatz, RA. \&Löhe, F. (2010).Tumor infiltrated hilar and mediastinal lymph nodes are an independent prognostic factor for decreased survival after pulmonary metastasectomy in patients with renal cell carcinoma.J Urol., 184(5):1888-94, 20846691.

Wu, HY., Xu, LW., Zhang, YY., Yu, YL., Li, XD. \& Li, GH. (2011). Metachronous contralateral testicular and bilateral adrenal metastasis of chromophobe renal cell carcinoma: a case report and review of the literature.J Zhejiang Univ Sci B., 11(5):386-9, 20443217.

Yokonishi ,T., Ito, Y., Osaka, K., Komiya, A., Kobayashi, K., Sakai, N., Noguchi, S., Kishi, H., Satomi, Y., Mogaki, M., Tsuura, Y., Mizuno, N. \&Ikeda, I. (2010).Pancreatic metastasis from renal cell carcinoma 25 years after radical nephrectomy.Hinyokika Kiyo. , 56(11):629-33, 21187708.

Yumura, Y., Yamashita, Y., Senga, Y., Jinza, S. \&Goro, A. (2007). Two cases of renal cell carcinoma with diabetes mellitus that was healed after nephrectomy.Hinyokika Kiyo. , 53(5):301-5, 17571714.

Zubac, DP., Wentzel-Larsen, T., Seidal, T. \& Bostad, L. (2010).Type 1 plasminogen activator inhibitor (PAI-1) in clear cell renal cell carcinoma (CCRCC) and its impact on angiogenesis, progression and patient survival after radical nephrectomy.BMC Urol., 10:20-4, 21129210.

Zustovich, F., Gottardo, F., De Zorzi, L., Cecchetto, A., Dal Bianco, M., Mauro, E. \&Cartei, G. (2008).Cardiac metastasis from renal cell carcinoma without inferior vena involvement: a review of the literature based on a case report. Two different patterns of spread?Int J Clin Oncol. , 13(3):271-4, 18553240.

Maestre-Rodríguez ,O., González-García, R., Mateo-Arias, J., Moreno-García, C., SerranoGil, H., Villanueva-Alcojol, L., Campos-de-Orellana, AM. \& Monje-Gil, F. (2009). Metastasis of renal clear-cell carcinoma to the oral mucosa, an atypical location.Med Oral Patol Oral Cir Bucal. , 14(11):e601-4, 19680203.

Mudiyanselage, SY., Prabhakaran, VC., Davis, GJ. \& Selva, D. (2008).Metastatic renal cell carcinoma presenting as a circumscribed orbital mass.Eur J Ophthalmol. , 18(3):4835,18465741 . 


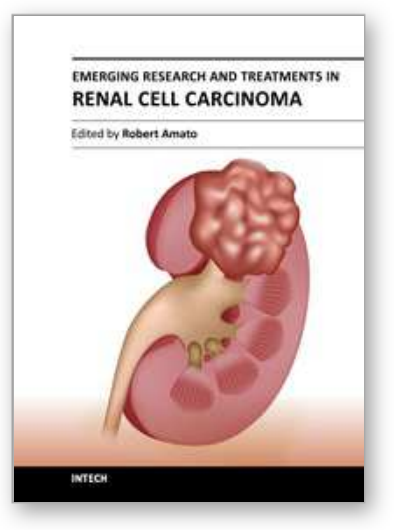

\author{
Emerging Research and Treatments in Renal Cell Carcinoma \\ Edited by Dr. Robert Amato
}

ISBN 978-953-51-0022-5

Hard cover, 442 pages

Publisher InTech

Published online 03, February, 2012

Published in print edition February, 2012

The field of renal cell cancer has undergone a significant resurgence. This book summarizes up-to-date research and innovative ideas for the future in this rapidly changing field, which encompasses medicine, surgery, radiation oncology, basic science, pathology, radiology, and supportive care. This book is aimed at the clinician or scientist who has an interest in renal cell cancer, whether they are academic or nonacademic. The book covers tumor biology, molecular biology, surgery techniques, radiation therapy, personal testimonies, and present and future treatments of the disease that are on the horizon. The goal was to produce a textbook that would act as an authoritative source for scientists and clinicians and interpret the field for trainees in surgery, medicine, radiation oncology, and pathology.

\title{
How to reference
}

In order to correctly reference this scholarly work, feel free to copy and paste the following:

Mehrnaz Asadi Gharabaghi (2012). Clinical Spectrum of Patients with Renal Cell Carcinoma, Emerging Research and Treatments in Renal Cell Carcinoma, Dr. Robert Amato (Ed.), ISBN: 978-953-51-0022-5, InTech, Available from: http://www.intechopen.com/books/emerging-research-and-treatments-in-renal-cellcarcinoma/clinical-spectrum-of-patients-with-renal-cell-carcinoma

\section{INTECH}

open science | open minds

\section{InTech Europe}

University Campus STeP Ri

Slavka Krautzeka 83/A

51000 Rijeka, Croatia

Phone: +385 (51) 770447

Fax: +385 (51) 686166

www.intechopen.com

\section{InTech China}

Unit 405, Office Block, Hotel Equatorial Shanghai

No.65, Yan An Road (West), Shanghai, 200040, China

中国上海市延安西路65号上海国际贵都大饭店办公楼 405 单元

Phone: +86-21-62489820

Fax: +86-21-62489821 
(C) 2012 The Author(s). Licensee IntechOpen. This is an open access article distributed under the terms of the Creative Commons Attribution 3.0 License, which permits unrestricted use, distribution, and reproduction in any medium, provided the original work is properly cited. 